УДК 341.1/8+340.116(53)

\title{
X. Бехруз \\ МЕЖДУНАРОДНОЕ И НАЦИОНАЛЬНОЕ ПРАВО: ПРОБЛЕМЫ ВЗАИМОДЕЙСТВИЯ НА ПРИМЕРЕ ПРАВОВЫХ СИСТЕМ ИСЛАМСКИХ ГОСУДАРСТВ
}

Взаимодействие норм исламского права и неисламских правовых норм: исторический ракурс. Наряду с нормами исламского права, определяющими особенности функционирования основных компонентов исламской правовой системы с первых дней ее существования, в ней присутствовали неисламские правовые нормы.

Начальный этап становления исламского права, как известно, был связан с появлением двух основополагающих источников исламской религии - Корана и Сунны, в которых содержатся также основные принципы и нормы исламского права, обеспечивающие правовое регулирование, прежде всего, отношения членов исламской уммы (общины). Однако, в связи с территориальным расширением границ Арабского халифата, общественные отношения все более усложнялись, и необходимость их регулирования детерминировала формирование новых источников права, способных на основе вышеуказанных источников регулировать общественные отношения, тем самым удовлетворить потребности общественного развития. В результате появления двух последующих источников исламского права - иджмы и кияса. На их основе была сформирована исламско-правовая доктрина, базировавшаяся, помимо основных источников исламского права, и на других правовых традициях. При этом главным условием выступала их непротиворечивость основным принципам исламского права.

Определенные положения, принципы и нормы римского права оказали как прямое, так и косвенное влияние на формирование отдельных положений исламского права. На некоторых территориях исламского халифата было санкционировано действие отдельных нормативно-правовых актов неисламского происхождения. С приходом династии Омаядов столица Арабского халифата была перенесена в Дамаск. В этот период в Сирии действовал Сирийско-римский кодекс, который вобрал в себя как нормы обычного права, так и многие положения римского права. После перехода мусульман действия многих положений этого уникального документа не было отменено. 
C первого периода существования исламской уммы (общины) на ее территории суды руководствовались как нормами исламского права, так и правовыми нормами неисламского происхождения, тем самым существовал дуализм судебной системы. Особо следует отметить действие «право конфессий», т.е. возможность решения вопросов, подлежащих регулированию религиозными нормами той или иной конфессии (вопросов заключения брака, наследования), в рамках конфессиональных судов. Необходимость существования светских судов была обусловлена многими факторами. Одна из причин состояла в конфессиональной неоднородности халифата, а также в развитии торговых отношений с другими государствами. Юрисдикция светского суда распространялась на разрешение спорных вопросов взаимоотношений членов исламской уммы, а также других граждан с представителями государственной власти.

Следующий этап эволюции исламского права, а также взаимодействия норм исламского права и неисламских правовых норм связан с периодом существования Османской империи. Хотя несколько веков в начальном периоде ее существования исламское право находилось в застойном состоянии, однако во второй половине XIX в. начинается период «исламской реформации». Эти реформы были обусловлены рядом факторов, в частности изменениями в политической, экономической и социальной сферах исламского общества под нарастающим влиянием западноевропейских государств. В частности, был провозглашен принцип равенства мусульман и немусульман перед законом, ставший, согласно Парижскому трактату 1856 г., международным обязательством Турции.

Если до середины XIX в. исламское право как система действующих норм, занимало ведущее место в правовых системах исламских государств, то, начиная с середины XIX в., в большинстве из них можно наблюдать ограничение применения правовых норм и институтов, которые сформировались под прямым влиянием классического исламского права. В сфере действия исламского права осталось регулирование, прежде всего, вопросов личного статуса мусульман.

Важным направлением реформирования правовых систем исламских государств в этот период являлась судебная система. Его суть заключалась в сужении сфер деятельности исламских судов, а в некоторых случаях - в их упразднении. Например, согласно Уголовно-процессуальному кодексу Египта для смешанных (1875 г.) и национальных (1883 г.) судов, основанных на заимствованных европейских образцах, преимущественно французских, ограничивалась сфера действия исламских судов, юрисдикция которых свелась, главным образом, к регулированию отношений личного статуса и правового положения вакфов. Этот процесс имел продолжение. Так, в Малайзии, согласно закону о мусульманском суде 1965 г., нормы классического исламского права применяются лишь на уровне морали и воспитательно-пропагандистской деятельности [1, с. 406].

Кодификация норм в правовых системах исламских государств в начале $\mathrm{XX}$ в. затронула сферу уголовного законодательства, ориентированного 
на западные образцы. В частности, примером может служить принятие в Иране Уголовного кодекса 1926 г., построенного на основе заимствования основных положений Уголовного кодекса Франции 1810 г. Необходимо отметит, что данный кодекс предлагал альтернативу любым исламским наказаниям в виде санкций, характерных для светского уголовного права.

Современная история развития исламских государств и обществ не является однозначной и поступательной в одном направлении. Это проявляется в том, что на протяжении всего XX в. не возобладало единое направление их развития. Начало XX в. характеризуется относительным ослаблением влияния исламско-правовой доктрины на развитие правовых систем исламских государств, и этот процесс сопровождается заимствованием правовых положений в рамках сформировавшихся национальных правовых систем исламских государств у западных правовых системах. Имплементация принципов и норм международного права, проводимая в рамках правовых систем исламских государств, осуществляется как одна из форм общения с внешним миром. Реформирование исламского права в направлении заимствования западных законодательных образцов, преимущественно из континентальной правовой системы, ощутимым образом повлияло на их правовую систему, а также на их государственное и общественное устройство. Однако во многом этот процесс привел не столько к ломке традиционного религиозного мировоззрения, сколько к использованию новых методов упорядочивания нормативно-правового материала, а именно - в виде отраслевых нормативно-правовых актов, которые не предусматривали существенных изменений религиозной основы регламентации. Этот процесс особенно проявляется в отношении регулирования «личного статуса». Таким образом, эти изменения затронули преимущественно формальные аспекты правовых систем исламских государств, а что касается его содержательных аспектов, то такое влияние является ограниченным.

Отказ от применения шариата, как справедливо отмечает Абдуллахи Ахмед Ан-Наим, психологически можно объяснить стремлением мусульман сохранить шариат в неприкосновенности хотя бы в теории, даже если его уже невозможно применять на практике. Мусульмане не могут больше уважать себя и гордиться собой, нарушая свой религиозный долг беспрекословно подчиняться требованиям ислама. Однако публичное шариатское право вызывает очень серьезные моральные и практические проблемы. Это противоречие между религиозной приверженностью исламскому праву и очевидным несоответствиям ряда аспектов этого права в его шариатской форме нормам современной. Исламское право должно быть адаптировано и приспособлено к условиям и потребностям современной жизни в контексте ислама в целом, даже если это предполагает пересмотр отдельных положений исторического шариата и более того - отказ от них [2].

Концепция исламскогомеждународного права. Исламская цивилизация зародилась в сложных условиях, когда взаимоотношения исламской уммы (общины) с другими племенами, обитавших на Аравийском полуострове, была враждебной. Исламская община на начальном периоде должна была 
бороться за свое существование, наладив отношения с соседними племенами, затем начался период ее завоевательных походов, благодаря которым происходит территориальное расширение Арабского халифата. В этот период можно говорить о существовании скорее межплеменных отношений. Однако после того как Арабский халифат завоевал значительную территорию, вопросы о его взаимоотношениях с другими государствами нуждались в межгосударственном правовом регулировании.

Арабский халифат граничил на северо-западе - с Византийской империей, а на северо-востоке- с Сасанидской империей. Применение силы или угроза ею считалось тогда нормой в отношениях различных племен и государств. Таким образом, к моменту образования Арабского халифата, именно применение силы определяло то, что сегодня интерпретируются как международные, точнее межгосударственные отношения. Поэтому исламское право должно было неизбежно регулировать отношения по поводу использования силы во взаимоотношениях мусульман с немусульманами, на уровне общин, племен и государств. Согласно доктрине исламского права исламское государство использовало силу, лишь того когда другая сторона отказывается от подчинения законам шариата.

Коран, как основной источник исламского права, содержит положения в отношении возможности применения силы, в частности «если они [лицемеры] отойдут от вас, не сражаясь с вами и предложат вам мир, то Аллах не дает вам никакого пути против них» [стих 4:90]. «И сражайтесь с ними [с неверными] пока не будет искушения и вера вся будет принадлежать Аллаху. А если они удержатся... ведь Аллах видит то, что они делают!» [Стих 8: 39].«А если они [неверные] склонятся к миру, то склонись и ты к нему и полагайся на Аллаха: ведь Он - слышащий и знающий» [стих 8:61] [3].

На основе этих положений, при проведении военных походов и попытках территориального расширения Арабского халифата

исламские полководцы предлагали противной стороне возможность принять ислам, при положительном решении запрещалось применения силы. В противном случае, если это касалось «людей писания», то им предлагалось заключить договор о зимме, который предполагал оплату джизьи (специального налога для немусульман) и подчинение власти мусульман. Взамен им обеспечивалась безопасность и защита, касавшейся их жизни и имущества. Если противная сторона оказывались немусульмане - не «люди писания», то им предлагалось возможность принять ислам, в случае отказа им предлагалось платить джизью. Только тогда, если предложения было отвергнуто, то разрешалось применение силы.

Доктринальная разработка исламского международного права была осуществлена исламским ученым Мухаммедом ибн ал Хасаном аш-Шайбани (749-805 гг.) в книге «Катаб ас-сийар ал кабир» (Большая книга об образе жизни), сохранившееся только в составе комментария ас-Сарахси [4].

Заслуживающей внимания является исламская концепция международного права, основанная на разделении мира на несколько групп: 
Дар аль-Ислам (Мир ислама) - это территория, находящаяся под юрисдикцией исламского государства, на которой распространяется шариат и соответственно на ней действуют нормы исламского права. Долгом каждого мусульманина является защищать данную территорию. На ней могут проживать и немусульмане, но при этом они должны подчиняться власти мусульман. Выделяется или Дар аль-Куфр (территория неверия) или Дар аль-Харб (Мир войны)- это территория тех государств, которые отказались принять ислам и считается враждебной по отношению к Миру ислама. Также выделяется Дар аль-Агд (Мир договора)или Дар ас-Сульх (территория перемирия) - это те территории, с которыми исламское государство договорилось о мирном сосуществовании. На данной территории не распространяется юрисдикция исламского государства, при этом проживающие мусульмане пользуются его защитой и религиозной свободой.

Необходимо согласиться с тем, что исламское международное право требует модернизации, благодаря которой сможет соответствовать современным потребностям исламских государств. В настоящее время предпринимаются попытки по приспособлению данной отрасли исламского права к современным реалиям. Так, активно разрабатываются такие вопросы, как: исламское государство в системе международных отношений; отношения исламского государства с международными организациями; участие в международных договорах и конвенциях. Рассматриваются также перспективы разработки проекта декларации по международному праву с точки зрения ислама [5, с. 153-154].

Влияние международного права на национальное законодательство исламских государств. Международное право - это система принципов и норм, регулирующих отношения властного характера между государствами и другими субъектами международного общения. K ним относятся отношения между государствами, между государствами и международными организациями, между государствами и государство подобными образованиями, между международными межправительственными организациями. Данные отношения составляют предмет международного права. Национальное право регулирует разнообразные общественные отношения внутри государства.

Взаимодействие международного и национального права имеет большое значение для функционирования данных правовых массивов. Нормы международного права могут быть реализованы на национальном уровне либо непосредственно (Selfexecuting), либо через процедуру имплементации(Implementation). В первом случае основанием для этого может служить то, что возможность применения некоторых норм международных договоров предусматривается национальным правом. В международных договорах, применяемых непосредственно, государственные органы, в особенности суды и другие правовые органы должны создать основу при принятии решения. Договор непосредственно применяется тогда, когда по своему содержанию он направлен на правовые органы или суд [6, с. 310].

Во втором случае, когда международно-правовые нормы не могут быть реализованы непосредственно, требуются имплементация этих норм, 
путем принятия соответствующего нормативно-правового акта на национальном уровне, в результате чего, положения и нормы международного права становятся частью национального права.

В формировании и функционировании современного международного права большую роль сыграли и продолжают играть исламские государства. У истоков создания ООН и разработки Устава ООН стояли такие исламские государства как Египет, Иран, Ливан, Сирия и Турция. Они стали первыми членами ООН. Затем к этому процессу сразу же присоединились Ирак, Афганистан, Пакистан, Йемен и др.

В настоящее время также исламские государства как субъекты международного права все активнее участвуют в международно-правовых отношениях, укрепляя свои политические и экономические позиции в современном мире.

Формирование нового глобализирующегося миропорядка, базирующегося на международном праве, порождает серьезные вызовы для религиозного сознания индивидуума и религиозных институтов в целом. Поэтому сегодня большинство исламских государств сталкиваются со сложными процессами внутренней трансформации, вызванной изменениями, как в пределах этих стран, так и за их границами.

Безусловно, современное международное право оказывает большое влияние на национальное право исламских государств. Это влияние носит специфический характер, где важнейшую роль играет религиозный фактор. Влияние религии здесь проявляется в сложных социально-политических, культурно-идеологических проблемах, обусловленных разнообразием их содержания и многогранностью форм, что, в свою очередь, определяет специфику путей их разрешения.

При имплементации международно-правовых норм в правовых системах исламских государств необходимо учитывать не только природу этих норм, но и особенности исторически сформировавшейся правовой системы, напрямую связанных с ее религиозным характером. Следовательно, правовые системы исламских государств подвергаются всесторонней трансформации, которая осуществляется не только с учетом специфики функционирования каждой национальной правовой системы, но и принципов и норм международного права.

Современный правопорядок характеризуется признанием приоритета принципов и норм международного права перед национальным. Действие этого принципа в рамках правовых систем современных исламских государств ограничивается важной оговоркой, не позволяющей его однозначного применения: в рамках этих государств могут применяться только те нормы и принципы международного права, которые соответствуют основным принципам исламского права, основанных на важнейших постулатах исламской религии.

Необходимо отметить, что согласно некоторым исламским международно-правовым доктринам, сохраняющим традиционные представления о примате исламского права перед международным, принято считать, что 
международный договор не является основным источником правового регулирования международных отношений. В ряде случаев это обусловливает необходимость дополнительного закрепления того или иного соглашения, заключенного с участием исламского государства, нормами традиционного исламского права. Примером может служить Кэмп-Дэвидское соглашение по Ближнему Востоку, подписанное в 1979 г. между Египтом и Израилем. Шейх университета аль-Азхар обнародовал специальную «фетву» (заключение знатоков исламской религии и исламского права), в которой утверждалось, что договор с Израилем не содержит положений несовместимых с нормами шариата и исламского права.

Взаимоотношение принципов и норм международного и национального права является предметом регулирования, прежде всего, конституционно-правовых норм исламских государств. В частности, в Преамбуле Конституции Мавритании, имеются ссылки на Африканскую Хартию прав человека от 28 июня 1981 г. и Общую Декларацию прав человека от 10 декабря 1948 г. [7], что подтверждает признание принципов и норм международного права. В Конституции Йеменской Народной Республики (ст. 5) содержится положение, согласно которому государство подтверждает свою приверженность нормам Устава ООН, Всеобщей Декларации прав человека, Уставу Лиги арабских государств и общепризнанным нормам международного права [8].

Вместе с тем имеется и иная практика, так в Конституции Судана (ст. 55) отмечается, что правовая система страны состоит из исламского права, конституции, принятой на референдуме и норм обычаев (адат). Однако здесь не отмечается какая-либо взаимосвязь с нормами международного права. Нет также упоминания о статусе международных договоров, которые ратифицируются страной или к которым она присоединяется. Лишь в ст. 73 Конституции отмечается функция национальной Ассамблеи об утверждении международных договоров и соглашений [9].

Конституционные нормы большинства исламских государств определяют форму и порядок имплементации норм международного права в национальное законодательство этих государств. Так, в Конституции государства Бахрейн отмечается, что положения того или иного международного договора или конвенции вступают в силу после ратификации правового акта и размещения в «Официальных новостях» [10]. После этого нормативно-правовые акты начинают иметь значение для государственных структур, отдельных граждан, иностранцев, и т.д. Так, в «Официальных новостях» от 28 февраля 1990 г. была опубликована Конвенция 1965 г. о ликвидации всех форм расовой дискриминации, тем самым Конвенция стала составным элементом законодательства Бахрейна и таким образом местные суды получили возможность на ссылку на указанный документ. В Конституции Султаната Оман (ст. 72) отмечается, что исполнение конституционных норм не противоречит международным договорам, заключенным с другими государствами и международными организациями. В то же время подчеркивается, что подобные соглашения и договоры вступают в силу после их ратификации [11]. 
Основные принципы международного права, закрепленные международно-правовыми документами, как демократия, равенство, свобода, уважение прав человека и др., также, получили отражение, в конституционном законодательстве исламских государств. Так, конституционные нормы данных государств содержат положения, закрепляющие равенство граждан перед законом, независимо от конфессиональной принадлежности. Конституция Афганистана (ст. 22) запрещает любую дискриминацию в отношении граждан и провозглашает равноправие граждан, включая женщин и мужчин перед Законом [12]. Представителям других конфессий предоставляются определенные права, такие как право на исповедование своей религии, право на применение норм законодательства, регулирующих вопросы «личного статуса» в соответствии с положениями исповедуемой религии, право на защиту со стороны государства, право на правосудие и другие.

Конституция Иранской Исламской Республики закрепляет положение в соответствии с которыми в отношении прав человека страна исходит из таких международных принципов, как равенство всех людей, отсутствие дискриминации не зависимо от расы, языка и богатства [13].

Базирующееся на основополагающих источниках исламской религии и получившее дальнейшее обоснование, и развитие в рамках исламской правовой доктрины, исламское право по-прежнему остается мощнейшим фактором, определяющим характеристику и особенности функционирования правовых систем исламских государств. Несмотря на имплементацию многих принципов и норм международного права, а также правовой аккультурации, в результате чего происходит заимствование правовых положений у западного права, особенности функционирования этих положений в рамках национального законодательства исламских государств определяются исламской правовой доктриной. Что касается содержательных аспектов правовой системы, то их функционирование в основном зависит от основополагающих принципов исламского права, основанных на исламской религии.

\section{Литература}

1. Правовые системы стран мира. Энциклопедический справочник/ отв. ред. А.Я. Сухарев. М. : НОРМА-ИНФА, 2001. - $840 \mathrm{c}$.

2. Абдуллахи Ахмед Ан-Наим На пути к исламское реформации. Гражданские свободы, права человека и международное право / Ахмед Ан-НаимАбдуллахи. - М. : Музей и общественный центр им. А. Сахарова, 1999. - С. 8.

3. Коран / пер. с араб. акад. И.Ю. Крачковского. - М. : Раритет, 1990. - 528 с.

4. Ибн Араби // Новая философская энциклопедия : в 4 т. / пред. науч.-ред. совета В.С. Стёпин. - 2-е изд., испр. и доп. - М. : Мысль, 2010.

5. Постановления и рекомендации Совета исламской академии правоведения (фикха) фетвы / пер с араб. М.Ф. Муртазина. - М. : Ладомир, 2003. - 278 с.

6. Jackson B.D. Status of Treaties in Domestic Legal System: A Policy Analysis / B. D. Jackson / / American Journal of International Law. - 1982. - № 86. - 385 p.

7. Конституция Исламской Республики Мавритании [Электронный ресурс]. - Режим доступа : http:/ / worldconstitutions.ru/?p=65.

8. Конституция Йеменской Арабской Республики [Электронный ресурс]. - Режим доступа : http: / / worldconstitutions.ru/?p=81.

9. Конституция Республики Судан [Электронный ресурс]. - Режим доступа : http:/ / worldconstitutions.ru / ?p=74. 
10. Конституция государства Бахрейна [Электронный ресурс]. - Режим доступа : http: / / worldconstitutions.ru/?p=79.

11. Конституция Султаната Оман/[Электронный ресурс]. - Режим доступа : http: / / worldconstitutions.ru/?p=88.

12. Конституция Исламской Республики Афганистан [Электронный ресурс]. - Режим доступа : http://worldconstitutions.ru/?p=24.

13. Конституция Иранской Исламской Республики [Электронный ресурс]. - Режим доступа : http: / / www.cis-emo.net/sites / default/files/imagesimce/constitution_of_iran.pdf.

\section{Ан н о т а ция}

Бехруз $X$. Международное и национальное право: проблемы взаимодействия на примере правовых систем исламских государств. - Статья.

Исследованы проблемы взаимодействия международного и национального права на примере исламских государств. Современное международное право оказывает большое влияние на национальное право данных государств. При этом такое влияние носит специфический характер, где важнейшую роль играет религиозный фактор. Отмечено, что взаимоотношение принципов и норм международного и национального права является предметом регулирования, прежде всего, конституционно-правовых норм исламских государств. Подчеркнуто, что, несмотря на имплементацию многих принципов и норм международного права, особенности функционирования этих положений в рамках национального законодательства исламских государств определяются исламской правовой доктриной.

Ключевые слова: международное право, национальное право, правовые системы, исламское право, исламские государства.

\section{Анот а ц і я}

Бехруз $X$. Міжнародне та національне право: проблеми взаємодії на прикладі правових систем ісламських держав. - Стаття.

Досліджено проблеми взаємодії міжнародного та національного права на прикладі ісламських держав. Сучасне міжнародне право має великий вплив на національне право даних країн. При цьому такий вплив носить специфічний характер, де найважливішу роль відіграє релігійний чинник. Відзначено, що взаємовідношення принципів і норм міжнародного та національного права є предметом регулювання, перш за все, конституційно-правових норм ісламських держав. Підкреслено, що, незважаючи на імплементацію багатьох принципів і норм міжнародного права, особливості функціонування цих положень у рамках національного законодавства ісламських держав визначаються ісламською правовою доктриною.

Ключові слова: міжнародне право, національне право, правові системи, ісламське право, ісламські держави.

\section{S u m m a r y}

Bekhruz Kh. International and national law: problems of co-operation on the example of the legal systems of the Islam states. - Article.

The problems of cooperation of international and national law are investigational on example of the Islam states. Modern international law has a great influence on the national law of these states. At the same time, such influence carries specific character, where a major role is played by a religious factor. It is noted that the relationship of principles and norms of international and national law is the subject of regulation, first of all, the constitutional and legal norms of Islamic states. It is emphasized that, despite the implementation of many principles and norms of international law, the specific functioning of these provisions within the framework of the national legislation of Islamic states is determined by Islamic legal doctrine.

Key words: international law, national law, legal systems, Islamic law, Islamic states. 